\title{
TÍTULOS ACADÉMICOS EN LA FACULTAD DE INSTRUMENTACIÓN QUIRÚRGICA
}

Palabras del Dr. Luis Carlos Taborda Ramírez

Vicerrector Académico

Mayo 17 de 2008

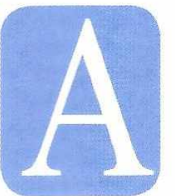

preciadas docentes y miembros distinguidos de nuestra comunidad académica convocados esta mañana para hacerles un público y merecido reconocimiento por las razones que me es muy grato y honroso exponer aquí.

Una de las grandes dimensiones constitutivas de la calidad de las instituciones y organizaciones en general, es la que en el lenguaje de los especialistas se designa como "talento humano" en el contexto del capital organizacional. Esto, que es fundamental para cualquier organización, cobra mayor importancia en el caso de una institución educativa y aún más cuando se trata de la educación superior, como es el caso de nuestra fundación académica y prestadora de servicios de salud.

No puede, en efecto, una institución educativa desarrollarse y legitimarse sin la vocación, dedicación, participación, lealtad y pertinencia de sus docentes con la casa donde se han educado y desarrollado su proyecto de vida, sirviéndole asi mismo a la vida de otros, en una relación de docencia y servicio.

Esto que estoy describiendo como una gran fortaleza institucional y condición de calidad y proyección de la misma, es lo que ustedes representan para la Fundación Universitaria de Ciencias de la Salud y nuestro venerable Hospital de San José y nuestro floreciente Hospital Infantil Universitario de San José.

Permítanme expresarles, en nombre de la institución que represento, cierto pesar por la tardanza en

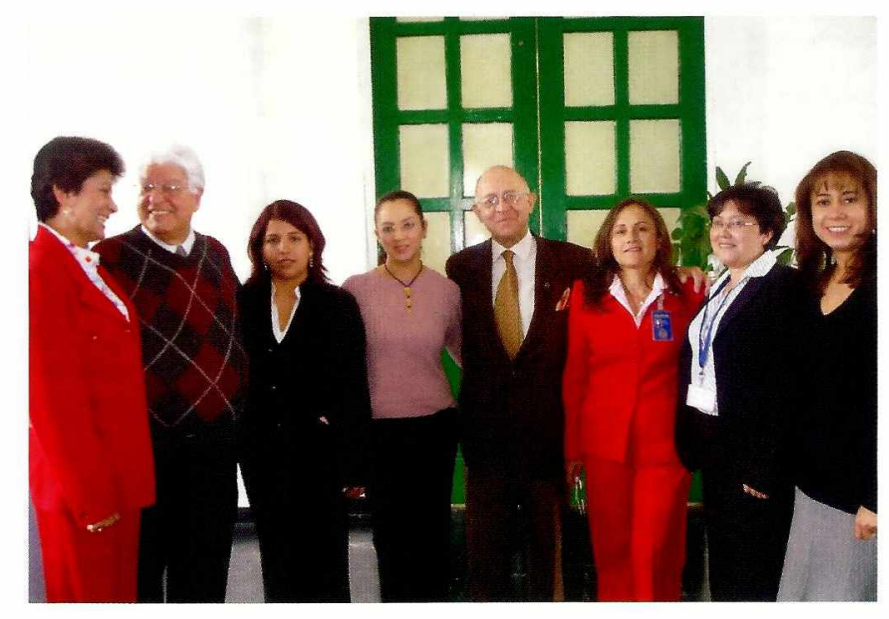

Grupo de profesoras de la facultad de Instrumentaciòn Quirúrgica con el rector de la Fundación Universitaria de Ciencias de la Salud Dr. Roberto Jaramillo U. y el vicerrector académico Dr. Luis Carlos Taborda R.

oficializar de manera formal y pública el respeto y el sentimiento de gratitud que siempre y auténticamente han sentido hacia la comunidad docente, todos los directivos y administradores de nuestra Sociedad de Cirugía desde el momento de su fundación. Así pues, en esta sencilla pero sentida y solemne ceremonia, les hacemos entrega de estos diplomas que certifican las diferentes titulaciones del escalafón docente, por su dedicación, talento, consagración y resultados.

Esta formalización pública de sus titulaciones, constituye, además, una forma de visualizar una de las fortalezas que se pueden mostrar y certificar dentro de los procesos de autoevaluación conducentes a la acreditación. El reconocimiento que hoy les hacemos, debe dinamizar aun más su apropiación, vivencia y compromiso con la realización de su vocación y su propio proyecto de vida.

De mi parte, reciban mis felicitaciones y mis más claros votos por sus continuos éxitos. 